\title{
JOVENS E DELINQUÊNCIAS: (SOBRE)VIVÊNCIAS NA FAMÍLIA
}

\author{
Maria João Leote de Carvalho ${ }^{1}$
}

\section{Introdução}

A problematização das práticas judiciais desenvolvidas junto de indivíduos referenciados a condutas desviantes ou delinquentes tem vindo a destacar-se, sobretudo na última década, como um dos temas mais vivos de debate público, sendo objecto de várias análises, tanto a nível nacional, como internacional. Provavelmente, a ênfase dada a esta problemática estará associada à importância que, progressivamente, vem a ser reconhecida à necessidade de uma mais eficaz acção preventiva, para a qual a detecção precoce de factores de risco se revela indispensável ${ }^{2}$.

O desvio, enquanto fenómeno de natureza social, remete para um abrangente campo de análise definido pelas interacções estabelecidas entre indivíduos, sociedades e os sistemas de normas que tendem a enquadrar e orientar a acção dos actores sociais num determinado contexto (Becker, 1963). Na perspectiva de vários autores (Cusson, 1989; Agra e Matos, 1997), está-se perante um conceito transdisciplinar que permite encontrar racionalidade em objectos sociais aparentemente tão díspares como o crime, a sexualidade, a droga, a doença ou a morte, entre outros. O ponto de partida deste artigo situa-se na abordagem ao desvio manifestado sob a forma de delinquência, que tem por autores crianças e jovens sujeitos à intervenção oficial do sistema de justiça tutelar de menores, em Portugal.

\footnotetext{
${ }^{1}$ Maria João Leote de Carvalho. Assistente de Investigação do SociNova - Gabinete de Investigação em Sociologia Aplicada da Faculdade de Ciências Sociais e Humanas da Universidade Nova de Lisboa.

${ }^{2}$ Este artigo tem origem numa dissertação de mestrado em Sociologia, especialização em Sociologia do Crime e da Violência, realizada sob a orientação do Prof. Doutor Nelson Lourenço, na Faculdade de Ciências Sociais e Humanas da Universidade Nova de Lisboa. A investigação em que assenta foi concretizada no âmbito de um protocolo firmado entre o SociNova e o Instituto Português da Droga e da Toxicodependência, o qual apoiou financeiramente o projecto.
} 
Num sistema social, tudo se encontra organizado em torno de instituições cujas funções objectivam a manutenção da estrutura social, importando que, na sua análise, uma especial atenção seja dada à variabilidade da percepção de norma e de desvio de sociedade para sociedade, de época para época. Se se considerar que na vida social deve haver um determinado tipo de ordem, sem a qual os seus membros não poderiam viver juntos, a quebra dessa ordem traz uma alteração encarada como um desvio social, cujos efeitos serão sentidos, quer pelo autor, quer pelos restantes autores, de forma mais ou menos profunda consoante o grau de afastamento à norma estabelecida (Merton, 1970). Uma infracção à norma só se torna relevante na condição desse acto ser socialmente reconhecido como tal, dando origem a uma reacção societal. Normatividade e desviância surgem não como universos opostos, mas como a dupla face dum mesmo facto social: para se poder explicar o desvio tem de se atender à normatividade pois onde existem normas existirá o desvio (Cohen, 1971).

$\mathrm{Na}$ medida em que a primeira condição que se coloca num sistema social é a existência de um acordo ou consenso entre os seus membros em torno de valores e meios instituídos na definição de um modelo que define fronteiras quanto ao grau de liberdade que um actor social aí dispõe, verifica-se que as normas sociais não se traduzem de forma automática em actos, exigindo dos indivíduos um controlo que, ao nível da sua acção, articule o pessoal e o social numa subordinação a interesses comuns (Becker, 1963).

Ao situar-se a delinquência como uma subcategoria do comportamento desviante, reportada a actos levados a cabo por crianças e jovens na quebra ou violação do estabelecido em quadros jurídicos (Binder et al., 2001), a sua emergência e a das problemáticas associadas implicam, numa perspectiva de análise sociológica, que se atenda ao facto de comportamentos desta natureza integrarem duas componentes: a do comportamento em si próprio e a da sua definição como desviante ou delinquente (Dias e Andrade, 1984).

Se por delinquir se entende a acção de cometer uma falta ou um delito no desrespeito pelos quadros de regras que uma sociedade legalmente tem instituídos (Matos, 1996), essa transgressão traduz uma ruptura relativamente aos limiares de tolerância dos grupos sociais portadores de sistemas de normas e de valores de uma sociedade, num dado momento da sua evolução (Selosse, 1976). Por efeito dessa transgressão vem a desencadear-se um mecanismo social de reprovação e de sanção, que traduz uma reacção colectiva que vai para além do quadro familiar e educativo, suscitando uma intervenção de natureza administrativa ou judiciária. Configura-se, então, como decisivo relevar que a delinquência, mais do que um problema de natureza jurídica é, antes de mais, um problema eminentemente social que obriga a uma maior implicação de toda a sociedade na procura de alter- 
nativas que objectivem a sua prevenção e combate (Rodrigues, 1997). Esta será uma das mais complexas tarefas cometidas a uma comunidade como parte essencial da prevenção do crime. Gradualmente, tem vindo a adquirir um conteúdo próprio no estabelecimento de uma jurisdição especial de protecção da infância e juventude, corporizada, em Portugal, no sistema de justiça tutelar de menores ${ }^{3}$. Deste modo, consagra-se a existência de direitos e deveres específicos nos princípios de um quadro jurídico que dá expressão a um sentimento comunitário que aponta para a necessidade de diferenciação de significado e de políticas de intervenção, a desenvolver em resposta aos actos delitivos praticados por crianças e jovens ou por adultos (Selosse, 1995).

De uma visão mais tradicional que entendia a criança ou o jovem como meros objectos da interacção social, as tendências mais recentes no campo da sociologia suscitam outros tipos de abordagem, destacando cada indivíduo como actor social, a diversos níveis, ao longo do seu processo de socialização (Cario, 1999). Neste sentido, crianças e jovens passaram a ser considerados titulares de direitos próprios cuja negação ou violação corresponde à aplicação de sanções, à luz de jurisdição específica ou geral. Não mais será possível falar de infância e juventude como se se tratassem de realidades planas, vividas ou representadas exclusivamente no singular; em cada uma destacam-se campos próprios que remetem para a co-existência de traços diversos decorrentes de regularidades assinaladas por origens de género, espaço social de classes e, até mesmo, local geográfico (Almeida, 2000).

Enquanto problema socialmente construído, a delinquência destaca a condição de jovem como etapa de socialização que só pode ser compreendida em relação ao contexto em que é vivida, reflectindo experiências com diversos agentes de socialização, de entre os quais se salientam a família, a escola, o grupo de pares e, no caso concreto do estudo que serve de base à apresentação deste artigo, instituições de controlo formal. A informação sobre a sua incidência e natureza não pode ser considerada isoladamente no mero conhecimento dos actos cometidos, tendo de ser analisada sob o ponto de vista dos quadros sociais e contextos de socialização do meio onde se produz, acreditando-se que a compreensão da complexidade da vida social pressupõe que se retenha que as estruturas e as dinâmicas sociais dificilmente se explicam a partir de causas únicas, sendo antes o resultado de agregações de múltiplos factores (Boudon, 1979).

\footnotetext{
${ }^{3}$ Sistema que não tem natureza cível relativamente a crianças ou jovens em risco social, nem natureza penal para menores de 16 anos; até esta idade são considerados inimputáveis perante a lei penal, só podendo ser-lhes impostas medidas tutelares.
} 
Os debates mais recentes acerca desta temática têm vindo a enfatizar a ligação entre influências de ordem social e o desenvolvimento deste tipo de comportamentos por parte dos jovens, designadamente, na relação com consumo ou tráfico de substâncias ilícitas (drogas) ou abusos de substâncias lícitas (tabaco, álcool, medicamentos), conscientes de que apenas se possui uma visão parcelar e menor deste problema, pela multiplicidade de contextos e variáveis que o atravessam (Rodrigues et al., 1997). O desenvolvimento de um olhar sobre os percursos de vida destes jovens deverá atender aos aspectos e limitações estruturais que dominam a interacção e as dinâmicas familiares nas quais se integram. É nos espaços de socialização familiar que muito da sua evolução foi influenciada, numa linha que poderá ter abarcado desde a resolução saudável e desdramatizante de um problema, quantas das ocasiões frequentemente menor, até à sua exclusão ou estigmatização (Queloz, 1994).

Moura Ferreira et al. (1993) apontam para uma generalização relativa de fenómenos de desvio e delinquência durante a juventude, podendo tais fenómenos encontrar as suas razões de ser na especificidade do desenvolvimento psicossocial juvenil e das situações dos jovens na própria sociedade, mais concretamente no seio de meios e culturas eminentemente juvenis, cujas representações, valores e normas poderão não ser coincidentes com os que dominam o mundo dos adultos, daí o emergir de um confonto entre o que ambas as partes consideram ser legítimo (Machado Pais, 1996). Da diferenciação funcional da violação de regras sociais pelo assumir de práticas delinquentes, os actos antinormativos no seio de um grupo podem revestir um valor funcional não apenas para os seus autores, mas, inclusivamente, para o próprio grupo (Vala, 1985).

A crescente visibilidade de alguns factos desta natureza e o reconhecimento da "incapacidade ou desadequação dos controlos informais da família, da escola e da comunidade para assegurarem a conformidade (das crianças e jovens) em relação às regras que se supunham desejáveis para as crianças" (Moura Ferreira, 1997: 915) destacam a delinquência como resposta a configurações sociais indesejáveis para o indivíduo, não se podendo considerar esse tipo de reposta como produtos de mecanismos sociais de nível diferente daquele em que se produzem as respostas legalmente aceitáveis. Com efeito, uma conduta que seja percepcionada à luz das normas vigentes como inadequada, deverá ser vista no contexto de um determinado e específico sistema que inclua também a resposta considerada adequada: torna-se fundamental perceber que uma não pode ser compreendida se a outra for ignorada (Catalano e Hawkins, 1996).

Em Portugal, duas novas leis, a Lei Tutelar Educativa (Ministério da Justiça) e a Lei de Protecção de Crianças e Jovens em Perigo (Ministério 
do Trabalho e da Solidariedade) $)^{4}$, entraram em vigor em 1 de Janeiro de 2001, substituindo o modelo consubstanciado na Organização Tutelar de Menores (OTM), diploma legal que nas últimas décadas serviu de enquadramento neste campo do sistema judicial. De entre o leque de medidas tutelares passíveis de aplicação a menores de 18 anos aí preconizadas, a mais grave reportava-se à colocação em regime de internamento em Colégio de Acolhimento, Educação e Formação do Instituto de Reinserção Social, do Ministério da Justiça ${ }^{5}$.

Falar do universo de jovens internados nestes colégios por decisão dos tribunais implica ter presente a diversidade de situações que, sob uma mesma capa e a um primeiro e superficial olhar, se ocultava. Referenciada como uma das populações de maior risco no desenvolvimento de potenciais trajectórias de marginalidade, exclusão social e criminalidade, integrava uma pluralidade de perfis sociais, cujos pontos comuns e diferenças interessa melhor conhecer. A este nível, são significativos os resultados obtidos por Rodrigues et al. (1997) em estudo realizado, em 1993, junto da população de menores em regime de internato em estabelecimentos tutelares da região de Lisboa, que apontam para a permanência de certos indicadores sociográficos ao nível da caracterização das dinâmicas e estilos de vida familiares. Destaca-se a predominância de famílias de baixo estatuto sociocultural e socioprofissional, de grande dimensão, apresentando disfunções, em especial, quanto a relações de autoridade, verificando-se ainda frequentemente situações de disrupção familiar (Rodrigues et al., 1997).

Partindo dos resultados obtidos recentemente numa investigação mais vasta realizada sobre a população dos colégios do Instituto de Reinserção Social, do Ministério da Justiça, na fase imediatamente anterior à entrada em vigor da Lei Tutelar Educativa (2001), este artigo centra-se na problematização de (sobre)vivências desses jovens na família consideradas a partir da caracterização do grupo doméstico de origem, à data da sua primeira colocação em colégio. Porque os dados recolhidos se reportam a momentos específicos, limitados no tempo, a visão que aqui se obtém dos seus percursos de vida é parcial e, mais do que se situar numa linha de continuidade (que seria apenas aparente), ressalva acontecimentos eventualmente cruciais na determinação da sua evolução.

\footnotetext{
${ }^{4}$ A intervenção tutelar educativa está reservada a jovens que, entre os 12 e os 16 anos, tenham praticado facto qualificado pela lei como crime, colocando em causa os valores jurídicos essenciais à vida social. A intervenção tutelar de protecção desenvolve-se relativamente a casos em que se verifique a ameaça dos direitos essenciais (cívicos, sociais, económicos e culturais) da criança, requerendo-se, deste modo, a actuação do Estado.

${ }^{5}$ Actuais Centros Educativos.
} 
Cada trajectória está entrecruzada por outras vidas, por outros sujeitos, inscrita num quadro de relações de interdependências que apelam a indicadores mais vastos ao nível familiar e de redes de sociabilidade no meio envolvente. A existência de pessoas de referência, em determinados campos da sua existência, revela-se determinante, de tal modo que a relação entre a probabilidade de desenvolvimento deste tipo de condutas por parte de crianças e jovens e a ausência de relações afectivas positivas com os pais constitui-se como um dos pontos mais bem documentados das teorias dedicadas ao estudo nesta área (Hirschi, 1969; Winnicot, 1977; Vala, 1985). No tipo de relação mantida com os pais, é a qualidade dos laços estabelecidos que se procurou conhecer, apontando-se para leituras mais abrangentes da realidade social, designadamente, em torno da importância da rede familiar no acesso a estruturas de oportunidades que possam dar a possibilidade de promover a evolução para outros caminhos que não os do desvio e da delinquência.

A pesquisa desenvolvida focou-se, exclusivamente, numa das múltiplas facetas que esta problemática pode assumir, identificando-a unicamente com a população-alvo da intervenção, na área de um sistema restrito, particular e bem específico: o sistema de justiça tutelar de menores.

\section{Aspectos metodológicos}

Centrando-se sobre a problemática do desvio e da delinquência juvenis na sociedade portuguesa, a investigação concretizada teve como ponto de partida o universo de jovens de ambos os sexos, com idades compreendidas entre os nove e os 18 anos que, por decisão judicial, se encontravam em regime de internamento nos catorze colégios do Instituto de Reinserção Social, nos últimos quatro meses de vigência da Organização Tutelar de Menores (1978), compreendendo-se, nestes termos, o período entre 1 de Setembro e 31 de Dezembro de 2000.

Acreditando-se que à definição de políticas sociais e execução de estratégias e modelos, a desenvolver institucionalmente neste campo, deve corresponder um mais profundo conhecimento sobre a realidade social, a pesquisa teve por principal objectivo conhecer a natureza e direcção das trajectórias de vida desses jovens, em período anterior à sua primeira colocação num dos colégios.

Nesta linha, vieram a ser identificadas as determinantes sociais emergentes nos contextos de socialização atravessados e nos quadros sociais onde estes jovens se inscreveram, recorrendo-se apenas a um ângulo de observação da realidade social: o olhar dos agentes dos mecanismos de 
controlo formal (técnicos de Reinserção Social, tribunais e autoridades policiais).

Para a realização deste estudo, optou-se por uma metologia quantitativa. O eixo metodológico central assentou na aplicação de inquérito por questionário, estruturado em torno de grandes áreas: identificação pessoal - sexo, idade, nacionalidade, naturalidade, origem étnica, documentação oficial, percurso dos não nascidos em Portugal -; grupo doméstico de origem à data da colocação em colégio; grupo parental ou seu substituto; inserção familiar/clima de relacionamento; problemáticas sociais sinalizadas na família; percursos institucionais anteriores; descendentes; residência e situação habitacional; saúde e consumos (lícitos e ilícitos); situação jurídica; escolaridade e trabalho; natureza e caracterização dos factos ilícitos. A principal fonte de informação foi o dossier tutelar individual para onde conflui toda a documentação oficial relativa a cada caso (relatório social, avaliação psicológica, informações judiciais, ocorrências por factos ilícitos e outros), tendo os dados sido recolhidos no local pela autora em cada um dos colégios.

Ao processo iniciado em Abril de 2000, com a realização de um estudo de caso numa dessas instituições, na aplicação exploratória de diferentes técnicas de análise (uni, bi e multivariada-factorial de correspondências múltiplas), seguiu-se a recolha de informação junto das equipas técnicas de todos os colégios, no período compreendido entre Outubro de 2000 e Março de 2001, e subsequente análise documental e tratamento da informação centrado numa análise estatística, descritiva, no recurso a técnicas uni e bivariadas (tabelas cruzadas simples), estas últimas não apresentadas neste artigo. Esta opção, assim como o não recurso a análises multivariadas anteriormente exploradas, resulta, em larga medida, da inexistência de um quadro de fundo alargado sobre a referida população que pudesse ter vindo a constituir-se como referência.

Daqui veio a resultar o traçar de um retrato sociográfico na fase de transição entre dois modelos jurídicos claramente diferenciados: a Organização Tutelar de Menores (1978) e a Lei Tutelar Educativa (2001). Desse retrato, apresentam-se nestas páginas apenas um conjunto de indicadores sociográficos relativos ao contexto familiar, tendo como base a informação trabalhada num primeiro nível de análise univariada. Procura-se evidenciar as regularidades e singularidades relativas aos sujeitos em análise, destacando os determinantes sociais que tendem a caracterizá-los a si e aos grupos domésticos de onde são oriundos.

A vasta abrangência do campo em análise, que incluía casos que variavam entre a vitimação e a delinquência, obrigou a que tivessem sido tomadas determinadas opções teóricas e metodológicas. Dada a diversidade de situações não exclusivamente reportadas à problemática em causa, se- 
leccionou-se, para objecto de estudo, um subuniverso constituído somente pelos indivíduos que tinham sido identificados no desenvolvimento de condutas desviantes (mendicidade e/ou prostituição) ou na prática de actos qualificados pela lei penal como crime, sendo que poderiam acumular, em simultâneo, as duas vertentes. De fora, ficaram os sinalizados por mera vitimação, internados nestes estabelecimentos como solução de último recurso, por não sido encontrada outra resposta.

\section{O universo em estudo}

No período em causa, o universo era constituído por 685 jovens para uma lotação prevista de 554 lugares. Desde já evidencia-se a sobrelotação do sistema, uma linha constante ao longo das duas últimas décadas. Constata-se uma clara predominância de indivíduos do sexo masculino, orientação comum em diversos estudos concretizados nacional e internacionalmente sobre sistemas oficiais de justiça (Cusson, 1989; Sousa Santos et al., 1998). Por escalão etário, os rapazes estão representados com uma maior incidência nos 14-15 anos, ao passo que as raparigas nos escalões mais velhos, 16-17 anos.

Quadro 1: Processo de delimitação do subuniverso em estudo

\begin{tabular}{|c|c|c|c|c|}
\hline & \multicolumn{3}{|c|}{ Indivíduos } & \multirow[b]{3}{*}{ Observações } \\
\hline & \multicolumn{2}{|c|}{ Distribuição por Sexo } & \multirow[b]{2}{*}{$\begin{array}{c}\text { Total } \\
\text { ‥ } \% \% \text { linha }\end{array}$} & \\
\hline & $\begin{array}{l}\text { Masculino } \\
\text { N.o\% linha }\end{array}$ & $\begin{array}{l}\text { Feminino } \\
\text { N.o\% linha }\end{array}$ & & \\
\hline $\begin{array}{c}\text { Lotação } \\
(14 \text { colégios })\end{array}$ & $\begin{array}{c}412 \\
(74,4 \%)\end{array}$ & $\begin{array}{c}142 \\
(25,6 \%)\end{array}$ & $\begin{array}{c}554 \\
(100 \%)\end{array}$ & - \\
\hline $\begin{array}{c}\text { Universo } \\
\text { (total de jovens afectos) }\end{array}$ & $\begin{array}{c}551 \\
(80,4 \%) \\
\end{array}$ & $\begin{array}{c}134 \\
(19,6 \%) \\
\end{array}$ & $\begin{array}{c}685 \\
(100 \%)\end{array}$ & $\begin{array}{l}\text { sobrelotação do } \\
\text { sistema }(123,6 \%)\end{array}$ \\
\hline $\begin{array}{c}\text { Dossiers tutelares } \\
\text { consultados }\end{array}$ & $\begin{array}{c}538 \\
(81,8 \%) \\
\end{array}$ & $\begin{array}{c}119 \\
(18,2 \%) \\
\end{array}$ & $\begin{array}{c}657 \\
(100 \%)\end{array}$ & $\begin{array}{l}\text { representativos de } \\
95,5 \% \text { do universo }\end{array}$ \\
\hline $\begin{array}{l}\text { Constituição do sub- } \\
\text { universo } \\
\text { (condutas desviantes } \\
\text { e/ou delinquentes) } \\
\end{array}$ & $\begin{array}{c}496 \\
(82,8 \%)\end{array}$ & $\begin{array}{c}103 \\
(17,2 \%)\end{array}$ & $\begin{array}{c}599 \\
(100 \%)\end{array}$ & $\begin{array}{l}\text { em estudo } 87,5 \% \\
\text { do universo } \\
\text { ( } 91,1 \% \text { do total de } \\
\text { dossiers cons.) }\end{array}$ \\
\hline
\end{tabular}

Fonte: Inquérito ao desvio e delinquência na população dos colégios do IRS, 2000.

Relativamente aos motivos que despoletaram a intervenção jurisdicional, 8,8\% (58: 42 rapazes; 16 raparigas) dizia respeito exclusivamente a vitimação (maustratos, abandono ou negligências), 15,2\% (100: 65 rapazes; 35 raparigas) fora referenciado a condutas desviantes (mendicidade e/ou prostituição) e 76\% (499: 431 rapazes; 68 raparigas) encontrava-se 
identificado na prática de acto qualificado pela lei como crime. Mais do que ressalvar a importância dos actos ilícitos praticados, o que estava na base da escolha de uma medida tutelar era a avaliação da personalidade e das condições de vida e situação familiar do jovem; os factos em si mesmos não podiam ser valorados senão como sintoma de inadaptação, não tendo sequer de ser provados (Gersão, 1994) ${ }^{6}$.

De assinalar que, na fase final de vigência da OTM, os casos de vitimação ainda se mantinham presentes num valor que, à data, assumia uma expressão elevada. Esta situação veio a arrastar-se no tempo e, em Outubro de 2001, eram ainda 27 os rapazes e raparigas que permaneciam nos centros educativos, em regime aberto ou semiaberto, por ausência de resposta de outros sistemas e da comunidade para que se concretizasse a sua saída da área da Justiça.

Mais de metade do subuniverso em estudo foi alvo de uma primeira intervenção tutelar entre os 9 e os 12 anos, embora a primeira colocação em colégio tenha ocorrido, com maior incidência, entre os 12-13 anos para o sexo masculino, e os 14-15 anos para os do sexo feminino.

As autoridades policiais destacam-se como principal entidade participante $(47,2 \%)$, seguindo-se os estabelecimentos de ensino (15,5\%). O maior volume processual corresponde aos Tribunais de Família e Menores de Lisboa (44,1\%) e Porto (26,4\%). Para 58,3\%, a colocação em colégio foi a primeira medida tutelar a que foram sujeitos, enquanto que os restantes já tinham sido alvo de uma ou mais. Neste campo, evidencia-se a colocação em estabelecimento oficial de educação (mais nas raparigas) e a admoestação (mais nos rapazes). Cerca de 9,3\% dos jovens veio a dar entrada em colégio, apesar de lhe ter sido aplicada pelo tribunal uma outra medida que pressupunha a sua execução noutro tipo de instituição que não na área da Justiça, num claro desfasamento entre a decisão judicial e a sua efectiva execução prática.

À luz dos resultados obtidos, cerca de um quarto dos jovens foi anteriormente objecto de colocação em instituição no sistema de Segurança Social, parecendo não ter existido uma desejável diferenciação de acções preventivas, situação que se agrava consideravelmente em determinadas faixas etárias (10-15 anos) e numa maior incidência junto dos rapazes. Apesar destes casos terem sido sinalizados oficialmente em idades muito novas, a intervenção oficial parece ter-se restringido, fundamentalmente, ao recurso à institucionalização, quer num como noutro sistema, ignoran-

\footnotetext{
${ }^{6}$ No âmbito da OTM, ao menor de 16 anos apenas podia ser considerada a suspeita da prática de um facto ilícito. A lei não previa a realização de julgamento em sede própria que asseguraria a consequente prova dos factos, não estando salvaguardas quaisquer garantias processuais, ficando a análise do caso sujeita a uma eventual discricionaridade por parte das entidades oficiais (Gersão, 2000).
} 
do-se necessidades de apoio psicossocial às famílias de onde são originários e onde se encontram assinalados factores de risco que poderão ter afectado a evolução dos seus membros.

$\mathrm{O}$ número de não nascidos em território nacional atinge os $7,0 \%$ do total da população, estando os rapazes sobrerrepresentados neste grupo. Também cerca de $27,0 \%$ das mães e $30,8 \%$ dos pais nasceu noutro país que não Portugal, surgindo como países estrangeiros de origem quase exclusivamente os PALOPs, com larga expressão para os oriundos de Cabo Verde. À volta de $44,9 \%$ não dispunha, ou não apresentou, à entrada no colégio, qualquer documento oficial de identificação. Nem todos os jovens nascidos em Portugal tinham nacionalidade portuguesa: $16,0 \%$ possuía nacionalidade estrangeira. A registar ainda o facto de $28,9 \%$ do total ser de origem africana e $3,5 \%$ de origem cigana.

As Áreas Metropolitanas de Lisboa e Porto, com uma especial relevância para a primeira, são as mais representadas, quer em termos da naturalidade, quer no que concerne ao último local de residência conhecido. Trata-se, predominantemente, de uma população oriunda de meio urbano e suburbano litoral, residente em habitações de precárias e deficitárias condições, situadas tanto em bairros sociais de realojamento $(39,4 \%)$ como em zonas de construção ilegal (barracas; prefabricados) $(25,2 \%)$. A estas condições alia-se a existência de um diminuto número de divisões para uma elevada dimensão dos grupos domésticos: cerca de um terço é oriunda de grupos numerosos, com sete ou mais elementos $(32,2 \%)$, destacando-se a seguir aqueles que integravam núcleos formados por quatro a seis pessoas $(40,0 \%)$.

Os seus percursos anteriores de escolaridade estão marcados pelo insucesso $(69,4 \%)$, pelo abandono precoce $(36,6 \%)$ e por uma fraca integração em medidas pedagógicas diferenciadas $(14,6 \%)$, registando as raparigas uma evolução escolar mais positiva que os rapazes. Para ambos, a conclusão do $1 .{ }^{\circ}$ Ciclo e consequente passagem ao $2{ }^{\circ}$ Ciclo revela-se como o momento-charneira decisivo para o prosseguimento ou não dos estudos. As experiências de trabalho ou de formação profissional são quase inexistentes.

Em termos globais, os actos ilícitos sinalizados sugerem a existência de modos de vida marcadamente atravessados por necessidades diversas de consumo, desde as mais básicas e elementares, traduzidas nos elevados valores de furtos de produtos alimentares, a outras vulgarmente não consideradas como fundamentais, mas cujos apelos crescentes a estas faixas etárias se fazem sentir, a vários níveis e em diferentes quadrantes, da sociedade portuguesa. Tais são os casos das roupas de marca, dos artigos de desporto e dos telemóveis. Daqui resulta um quadro de análise que destaca a existência de uma delinquência especialmente centrada em torno das designadas incivilidades (Roché, 1998), nas pequenas acções mais contra o 
património do que contra as pessoas, nos repetidos furtos com vista à posse de determinados bens, em detrimento de outros, sempre perturbadores da ordem social, pela frequente visibilidade de actos concretizados quase sempre em espaços públicos e em pequeno grupo. Não se revela muito expressiva, sob um ponto de vista meramente estatístico, a existência de casos que remetam para uma maior diversificação em termos de formas de actuação mais estruturadas e de natureza mais complexa dos actos ilícitos presumidamente cometidos.

Apesar disso, não deixa de ser significativo que se detectem, em alguns destes jovens, evoluções em termos de percurso delinquente que tende a reflectir uma maior quebra e crescente afastamento às normas espelhada na passagem para outros patamares de actuação mais graves, num reforço de uma trajectória acentuadamente desviante. Também clara parece ser a especialização de alguns em certas áreas, muito concretamente, no campo dos actos ilícitos de natureza sexual.

Recordando que se trata de uma abordagem centrada exclusivamente naqueles que já foram alvo de uma etiquetagem jurídica, a visão obtida acerca desta problemática fica limitada aos casos recenseados oficialmente, a um momento específico, num sistema que se apresenta como a ponta da pirâmide dos litígios do aparelho judicial. São, pois, alguns dos mais importantes resultados da investigação, relativos ao contexto familiar de origem destes jovens, que se passa de seguida a apresentar.

\section{O grupo doméstico: espaço de contrastes}

A par das profundas transformações demográficas, culturais, políticas, económicas e sociais ocorridas nas últimas décadas na sociedade portuguesa, a realização recente de pesquisas centradas na família tem vindo a promover o desenvolvimento de outros olhares sobre a diversidade e complexificação de modelos e formas familiares que apontam para uma reformulação de conceitos e para novas leituras sobre a realidade social (Kellerhals et al., 1979) ${ }^{7}$. Não sendo esta diversidade um facto novo, exclusivo do tempo presente, já a expressão que alguns dos seus contornos hoje adquirem torna a definição do conceito de família objecto de especial cuidado. Diversamente da sua variação quantitativa, é ao nível da sua estrutura e da natureza das dinâmicas familiares que se vêem reflectidas as mais importantes transformações.

\footnotetext{
${ }^{7}$ As "formas familiares" são aqui entendidas à luz do defendido por Almeida et al. (1998, p. 50), isto é, na consideração da "dimensão, e no tipo de família e de agregado doméstico em que estão inseridos os indivíduos".
} 
Acreditando-se que a palavra família encobre uma tal pluralidade de situações, Roussel (1992) vai mais longe ao defender a ideia que nos tempos actuais não é possível falar de família se não no plural, isto é, em famílias.

É, pois, à luz desta diversidade e perante as características da população em causa, e da natureza da própria informação recolhida, que neste estudo se veio a optar por centrar o interesse na caracterização do designado grupo doméstico, sendo este definido como o espaço partilhado pelo indivíduo enquanto unidade de co-residência (Almeida et al., 1998). Embora possa não cobrir a totalidade das relações de parentesco, nem a totalidade das relações sociais dos seus membros, acredita-se que o grupo doméstico consegue, ainda assim, "representar a parte mais perceptível e, ao mesmo tempo, mais estruturante, do universo familiar" (Burguière, 1986: 640).

Nenhuma forma de acção social se processa num espaço não estruturado. Por muito que determinados espaços, à primeira vista, não o deixem transparecer, a todos subjaz um determinado tipo de estrutura, eventualmente até distante dos tipos dominantes num dado contexto. Determinante na dimensão organizacional da acção humana, o estudo do grupo doméstico poderá revelar a margem de liberdade de acção dos actores sociais nele integrados assim como trará também à superfície o conjunto de factores exteriores que, por outro lado, o condicionam e nele interferem. Estes factores, consubstanciados nas condições materiais e sociais efectivas no seu contexto de acção, estão enquadrados, de modo mais abrangente, pelas estruturas e padrões sociais vigentes à época. No entanto, é de assinalar também que as acções e comportamentos desenvolvidos não se podem reduzir aos constrangimentos gerais subjacentes aos contextos de acção, embora não possam, de igual forma e em sua consequência, discernir-se deles.

No recurso à análise do grupo doméstico de origem dos jovens que se constituem como objecto de estudo, evidencia-se a família como um dos lugares privilegiados de construção social da realidade nas suas dimensões de espaço físico, relacional e simbólico (Saraceno, 1997). O tratamento da informação neste campo vem revelar os contornos da organização familiar, ressalvando como decisiva a natureza construída e, consequentemente, em evolução do conceito de família, geralmente difuso sob uma capa de aparente coerência e constância de acção social.

Situar cada um no presente implica que se atenda à forma como no seu passado se veio a conciliar o individual, o familiar e o colectivo. Não se trata de desenvolver aqui uma análise de modos de vida, mas antes apenas da sinalização e problematização de indicadores associados aos espaços de socialização atravessados nos seus percursos de vida.

Se parece certo que as famílias sofrem constrangimentos estruturais que as moldam e afectam a sua dinâmica interna e de relação com o exterior, também será verdade que, até determinado ponto, dispõem de uma 
autonomia que lhes permitirá, mesmo quando sujeitas a condições sociais similares, apresentarem modos de resposta diferenciados às situações.

A emergência de determinadas formas de (re)composição familiar vem pôr em evidência outros indivíduos, para além do pai e da mãe, que vieram a ocupar um lugar de destaque nestes grupos domésticos, a maioria das vezes de forma abrupta perante vivências familiares marcadas por circunstâncias pessoais e sociais de perdas, rupturas, negligências e abandono. Dificilmente, as situações são apresentadas de forma linear e continuada, surgindo contradições e descontinuidades num crescendo reportado a quebras sucessivas de laços sociais.

Bourdieu (1979) admite a existência de trajectórias de vida individuais, resultantes do desvio em relação à trajectória de vida modal, entendida esta como a trajectória mais previsível e frequente, em função de determinado volume de capital herdado, isto é, do capital económico, cultural e social possuído. No entanto, chama a atenção para o facto de as estratégias que conduzem a essas diferentes trajectórias se constituírem como produção de meros ajustamentos às condições objectivas dos agentes. Nesta linha, a família é o lugar onde se produzem as competências necessárias em dado momento, salientando-se que há estratégias de acção que somente se definem na relação entre membros do grupo doméstico e que determinam a sua evolução posterior. As trajectórias individuais terão de ser vistas como resultado de combinações particulares das estruturas englobantes com as oportunidades estratégicas, legítimas ou não. É aí que se opera e resolve, a um nível mais restrito, a regulação dos conflitos entre os mais directamente envolvidos, assegurando-se a articulação entre interesses e objectivos de natureza individual e colectiva.

Remetendo-se para lógicas de acção e para orientações a curto, médio ou longo prazo, a cuja significação mais profunda não se tem acesso nesta investigação limitada que está à análise dos documentos oficiais e ao discurso dos agentes das instâncias de controlo formal, os fragmentos analisados dos quadros de vida aqui postos em causa atravessam as múltiplas dimensões da actividade pessoal e social, constituindo-se como uma complexa e emaranhada teia onde os actores sociais se entrelaçam numa tradução de dupla pertença, relativamente a constrangimentos estruturais e à liberdade de acção que, eventualmente, puderam gozar.

\section{Natureza do grupo doméstico}

Tendo como objectivo a identificação da composição dos grupos domésticos de origem à data da entrada em colégio, tomou-se como ponto de partida a tipologia proposta por Peter Laslett, e o designado Grupo de 
Cambridge (1972), que veio a revelar-se como a mais adequada por abranger, ainda que com as devidas adaptações, a diversidade de casos caracterizados nesta população. Perante os grupos originalmente construídos ${ }^{8}$, mantiveram-se seis categorias, mas houve a necessidade de substituir os designados isolados pelos não integrados em grupo doméstico da família biológica (16,3\%). Para efeitos desta investigação, integram-se nesta modalidade as situações em que os jovens se encontravam em família de acolhimento ou adopção, em colocação institucional, ou foram sinalizados a viver autonomamente. Consideram-se nestes últimos aqueles em que não foi possível a detecção de um grupo doméstico onde pudessem estar integrados por, na maioria das vezes, se encontrarem a viver na rua há algum tempo. As restantes categorias são constituídas pelos grupos domésticos não conjugais $(4,8 \%)^{9}$, simples $(51,3 \%)^{10}$, alargados $(18,1 \%)^{11}$, extensos $(1,7 \%)^{12}$, e, por fim, outras combinações $(7,8 \%)^{13}$.

Somente $83,7 \%$ se mantinha ligado directamente a familiares, destacando-se os que provinham da família nuclear, seguidos pelos oriundos de famílias monoparentais, onde o adulto presente era, com maior incidência, a mulher.

Da análise do quadro 2, realça-se o número de não integrados em qualquer grupo doméstico com ligação à família $(16,3 \%)$ e, de entre estes, os sinalizados a viver autonomamente (8,2\%), tendencialmente na rua, porque aí se esconde uma diversidade de situações que não pode ser ignorada. À semelhança do que verificou João Sebastião, em estudo realizado na cidade de Lisboa (1995), tornou-se necessário distinguir os principais contornos identificados neste grupo.

\footnotetext{
${ }^{8}$ A tipologia de Laslett (1972) compreendia seis grandes grupos: isolados; agregados não conjugais, agregados familiares simples, agregados familiares alargados, agregados familiares multiconjugais e outras combinações.

${ }^{9}$ Grupos onde o jovem vive com um ou mais familiares sem que haja a presença de um núcleo conjugal (casal). São os casos dos que viviam com irmão(s), com um avô ou uma avó (linha ascendente) ou com outro(s) familiar(es) em linha colateral, podendo até haver em simultâneo a presença das linhas familiares mencionadas.

10 Incluem-se nesta categoria a família monoparental (um dos progenitores + filhos); a família nuclear (pai e mãe + filhos); e a família recomposta (um dos progenitores + substituto do outro - madrasta/padrasto/companheiro(a) + filhos).

11 Partindo dos 3 tipos de grupos simples - monoparental, nuclear ou recomposta -, são aqui designados aqueles que integram também outros familiares, seja em linha ascendente, seja em linha colateral.

12 Tendo presente a família nuclear, estes grupos referem-se a arranjos multinucleares que podem compreender outro(s) casal(is) em linha ascendente e/ou colateral.

13 Não está presente qualquer dos progenitores, sendo os restantes elementos do grupo doméstico familiares em linha ascendente e/ou colateral sob a forma de grupo nuclear (1 casal) ou multinuclear (mais do que 1 casal).
} 
Quadro 2: Natureza do grupo doméstico que integrava à entrada em colégio

\begin{tabular}{|c|c|c|}
\hline Categorias/classes & $\mathbf{N}$ & $\%$ \\
\hline 1. - Grupos domésticos não conjugais & 29 & $4,8 \%$ \\
\hline 1.1. - irmãos & 5 & $0,8 \%$ \\
\hline 1.2. - ascendentes & 10 & $1,7 \%$ \\
\hline 1.3. - colaterais & 10 & $1,7 \%$ \\
\hline 1.4. - ascendentes + colaterais & 4 & $0,6 \%$ \\
\hline 2. - Grupos domésticos simples & 307 & $51,3 \%$ \\
\hline 2.1. - família monoparental simples & 103 & $17,2 \%$ \\
\hline 2.2. - família nuclear simples & 139 & $23,2 \%$ \\
\hline 2.3. - família recomposta simples & 65 & $10,9 \%$ \\
\hline 3. - Grupos domésticos alargados & 109 & $18,1 \%$ \\
\hline 3.1. - família monoparental alargada & $(51)$ & $(8,5 \%)$ \\
\hline 3.1.1. - ascendentes & 15 & $2,5 \%$ \\
\hline 3.1.2. - colaterais & 20 & $3,3 \%$ \\
\hline 3.1.3. - ascendentes + colaterais & 16 & $2,7 \%$ \\
\hline 3.2. -família nuclear alargada & (29) & $(4,8 \%)$ \\
\hline 3.2.1. - ascendentes & 7 & $1,1 \%$ \\
\hline 3.2.2. - colaterais & 20 & $3,3 \%$ \\
\hline 3.3.3. - ascendentes + colaterais & 2 & $0,4 \%$ \\
\hline 3.3. - família recomposta alargada & (29) & $(4,8 \%)$ \\
\hline 3.3.1. - ascendentes & 8 & $1,3 \%$ \\
\hline 3.3.2. - colaterais & 13 & $2.2 \%$ \\
\hline 3.3.3. - ascendentes + colaterais & 8 & $1,3 \%$ \\
\hline 4. - Grupos domésticos extensos & 10 & $1,7 \%$ \\
\hline 4.1. - família multinuclear - linha ascendente & 3 & $0,5 \%$ \\
\hline 4.2. - família multinuclear - linha colateral & 2 & $0,4 \%$ \\
\hline 4.3. - família multinuclear - linhas ascendente e colateral & 5 & $0,8 \%$ \\
\hline 5. - Outras combinações & 47 & $7,8 \%$ \\
\hline 5.1. grupo nuclear & (32) & $(5,3 \%)$ \\
\hline 5.1.1. - ascendentes & 9 & $1,5 \%$ \\
\hline 5.1.2. - colaterais & 5 & $0,8 \%$ \\
\hline 5.1.3. - ascendentes + colaterais & 18 & $3,0 \%$ \\
\hline 5.2. - grupo multinuclear & $(15)$ & $(2,5 \%)$ \\
\hline 5.2.1. - ascendentes + colaterais & 15 & $2,5 \%$ \\
\hline 6. - Não integrado em grupo doméstico da família biológica & 97 & $16,3 \%$ \\
\hline 6.1. - em família de acolhimento e/ou adopção & 8 & $1,3 \%$ \\
\hline 6.2. - em colocação institucional & 40 & $6,8 \%$ \\
\hline 6.3. - sinalizado autonomamente & 49 & $8,2 \%$ \\
\hline TOTAL & 599 & $100 \%$ \\
\hline
\end{tabular}

Fonte: Inquérito ao desvio e delinquência na população dos colégios do Instituto de Reinserção Social, 2000.

Trata-se, na óptica dos autores dos documentos oficiais, de jovens cujas redes sociais, passíveis de conhecimento à data da intervenção, assentavam fundamentalmente em grupo(s) de pares e, a determinados níveis mas em muito menor número, na ligação a uma ou outra figura 
adulta, cuja caracterização raras vezes era feita. Como referenciado, isso decorre, sobretudo, de dificuldades de contacto e obtenção de mais informação, ficando-se restrito, na maioria das vezes, a uma descrição vaga feita por terceiros ou pelas indicações dadas pelo próprio jovem. $\mathrm{O}$ desconhecimento sobre os seus modos de vida, para além das vivências descritas como tidas na rua, é o que sobressai pela inexistência de elos de ligação à família ou a grupo doméstico substituto que terão integrado anteriormente.

Dificilmente se pode falar, nestes casos, de um processo de autonomização consistente, estruturado e devidamente procurado; antes pelo contrário, sobrepõem-se vivências marcadas por rupturas aos mais diversos níveis, em idades muito novas que apontam para uma falsa e desesperada autonomia.

Neste campo, perante o corte de relacionamento entre o jovem e a família, emergem três processos de natureza (aparentemente) oposta, mas que tenderão a reforçar-se mutuamente na reprodução de um círculo difícil de quebrar.

O primeiro parte de uma rejeição por parte dos pais, contemplando dois níveis de actuação: um em que essa rejeição é assumida claramente, traduzindo-se na expulsão directa do jovem para fora de casa ou do espaço que habitariam, impedindo-o de voltar a entrar aí; outro em que a rejeição se revela sob a forma de negligência, desamparo ou abandono, havendo um movimento, até certo ponto, diverso na medida em que são os pais que deixam o grupo doméstico e quebram os laços que poderiam existir, quanto mais não fosse pela sua presença física.

Um segundo processo abrange os casos em que a saída para a rua parece centrar-se numa iniciativa do próprio jovem, culminando, geralmente, um percurso anterior marcado por constantes fugas. No entanto, quando olhada mais profundamente, esta acção parece surgir como produto de uma organização e dinâmicas familiares em que a face visível de ruptura acabará por traduzir um conjunto de quebras de laços familiares, expressas sob as formas de abandono, negligência ou violência doméstica, que têm como principal agente não o jovem mas, especialmente, os seus familiares. Apenas em poucos casos parecem, de facto, resultar de uma actuação do próprio indivíduo, no sentido de uma opção possivelmente marcada pelo desejo de independência e de aventura, na fuga ao controle familiar (Castro, 1997).

$\mathrm{O}$ terceiro processo diz respeito às situações em que se regista a perda por falecimento ou a ausência decorrente de detenção ou hospitalização de um dos progenitores. A dada altura, a estrutura familiar viu-se atingida, na maior parte das vezes de forma inesperada, reflectindo-se isso na ausência de referências estáveis. Nos casos extremos, os mais novos acabaram por ficar exclusivamente entregues a si próprios, de um momento para o outro. A rua parece, então, emergir como mero prolongamento da casa, 
numa espécie de vaivém em que a não existência de supervisão familiar é o ponto dominante.

Todos estes processos, não sendo estanques, uma vez que em determinados momentos se podem ter cruzado e sobreposto, apontam para a existência de percursos de vida marcados por alterações constantes na esfera do relacionamento familiar. À luz dos resultados obtidos, estas situações dificilmente surgem de modo isolado, constantemente marcadas por quebras de laços familiares e sociais que assumem contornos potencialmente violentos e dolorosos em idades precoces.

Os mais atingidos são, predominantemente, os rapazes, variando o escalão etário em que isso aconteceu. A duração do período temporal relativo ao momento compreendido entre essa saída e o conhecimento oficial da situação, decorrente da intervenção tutelar, é também variável: pode ter acontecido no próprio dia, ao fim de poucos dias ou semanas, meses ou até mesmo após um período superior a um ano. Não se verifica neste campo a predominância de um tipo de estrutura familiar em relação a outro.

Outro dado relevante nesta análise prende-se com o facto de nos agregados onde surge um maior número de pessoas isoladas junto do jovem (um tio ou uma tia, um avô ou uma avó, um irmão) existir, também, uma maior associação à presença de indivíduos do sexo masculino. Estes dados poderão configurar uma actuação diferenciada em situações de risco, à partida tendencialmente similares, por parte dos familiares, conforme o género do jovem. Neste sentido, poder-se-á apontar para uma eventual maior mobilização de membros da família biológica, nos casos em que se trata de raparigas (sobrerrepresentadas nas famílias recompostas e outras combinações), ao contrário do que parece vir a ocorrer com os rapazes, geralmente, mais entregues a si próprios ou a apenas um familiar isolado desde muito cedo.

Bastante significativo é o facto de apenas $23,2 \%$ da população em estudo ter integrado sempre o mesmo grupo doméstico até à sua entrada em colégio. Existe um número elevado em que as mudanças conhecidas e as passagens por grupos diferenciados foram sucessivamente acontecendo $(76,8 \%)$, geralmente, por curtos períodos de tempo.

Como se de um mero objecto se tratasse, tipo uma bola de ping-pong, o jovem viu-se entregue a um sem-número de situações diversas que, de comum, terão uma carga emocional negativa. Reportando-se a mudanças, tendencialmente, abruptas, traduzidas num corte na interacção com os que lhes estavam mais próximos, a instabilidade e a constante alteração do quadro familiar e do(s) grupo(s) doméstico(s), ou do meio institucional que integrava, potenciaram a ausência de relacionamentos mais estáveis e duradouros que, de uma forma ou outra, se repercutem no seu desenvolvimento psicossocial (Winnicot, 1977) e no qual as condutas des- 
viantes ou delinquentes constituirão apenas a face visível de uma complexa e emaranhada teia difícil de desfazer (Ferreira, 2002).

\section{Entre pais e filhos}

Ao analisar a estrutura familiar, apenas em $24,9 \%$ da população se mantinha a presença física dos pais, em simultâneo, no grupo doméstico (famílias nucleares e extensas), emergindo nos restantes $75,1 \%$ diversas problemáticas associadas a uma $1 .^{\mathrm{a}}$ ruptura identificada no grupo parental. Destaque para os $28,9 \%$ que não contavam nem com a presença do pai, nem com a da mãe, ficando aqui bem claro o "equilíbrio perdido" (Ferreira, 2002: 51) que marca os ainda curtos percursos de vida de muitos destes jovens, vítimas em idades precoces de vivências decorrentes de abandono e de ausência de uma adequada supervisão por parte dos seus progenitores.

Quando se toma em linha de conta o motivo apontado nos documentos analisados como estando na base da primeira ruptura do grupo parental conhecida oficialmente ${ }^{14}$, o abandono é a modalidade mais representada, abrangendo mais de um terço da população $(34,9 \%)^{15}$. Trata-se de situações em que pai ou mãe, ou os dois em conjunto (15\%), abandonaram, sem razão aparente ou identificada, a casa, na maioria das vezes, sem referência a um outro motivo que não o do mero acto em si. Se, por um lado, o abandono de ambos atinge mais os rapazes, num sentido inverso são as raparigas que se vêem sobrerrepresentadas nos casos de abandono isolado por parte de um, seja a mãe, seja o pai.

A estas situações acrescem outras da mesma natureza, em que o motivo identificado da $1 .^{\text {a }}$ ruptura no grupo parental foi o falecimento ou a detenção de um dos pais, seguido do abandono posterior, imediato ou num muito curto prazo, do outro. Revela-se uma faceta do abandono que permanece oculta à primeira vista e que agrava a existência desta problemática no seio da população em estudo, por estar associada a uma outra perda ${ }^{16}$.

14 Teve-se em linha de conta o motivo identificado nos relatórios como o da $1 .^{\text {a }}$ ruptura conhecida no grupo parental, conscientes que outras poderão ter ocorrido e não ser do conhecimento oficial à altura.

15 Houve a necessidade de introduzir uma categoria relativa ao abandono que não se sobrepusesse à de divórcio/separação, por esta dizer respeito aos casos de relações de natureza conjugal (casamento, união de facto) em que tal foi identificado em momento anterior ao do abandono.

16 Em 2,8\% da população, ao falecimento do pai tem lugar o abandono quase de seguida por parte da mãe. Na situação inversa existem $2,5 \%$. Existem $1,2 \%$ de casos em que à detenção do pai se seguiu o abandono por parte da mãe e $0,9 \%$ em que à detenção da mãe sucedeu o abandono do pai. 
São indicadores que mesmo com um reduzido valor estatístico não devem, de forma alguma, ser subavaliados sob um ponto de vista social por se reportarem a franjas da sociedade portuguesa onde processos de sucessivas rupturas e perdas a nível familiar vêm a repercurtir-se num conjunto de necessidades, em termos de apoio, em áreas como a segurança social, educação, saúde, emprego e outras que nem sempre encontrarão a resposta mais adequada.

Outro dado desta investigação aponta para a existência de uma elevada taxa de mortalidade no seio destas famílias, em idades relativamente novas. Considerando apenas o falecimento de um dos progenitores, 13,1\% dos pais e 4,5\% das mães morreram numa idade que corresponde ao período da vida profissional activa. Em $1,4 \%$ do total da população ocorreu o falecimento de ambos, num período de tempo muito curto (inferior a 6 meses), sobretudo junto de raparigas. Neste campo, a figura paterna é claramente a mais atingida. As causas da morte conhecidas estão associadas, na maioria das vezes, a consumos abusivos de substâncias lícitas e ilícitas. Neste ponto, registam-se diferenças relativamente aos indicadores nacionais sobre mortalidade que destacam em Portugal as mortes por acidente de trabalho, sendo que, aqui, estão mais referenciadas as associadas ao abuso de álcool e drogas e a doenças infecto-contagiosas. Existe um restrito número de casos em que pai ou mãe foram vítimas de homicídio. O suicídio abrangeu $4,3 \%$ dos progenitores, não se diferenciando de forma significativa por sexo.

No que diz respeito à detenção $(15,9 \%)$, os que viram ambos os pais ser detidos em simultâneo ou num período de tempo relativamente curto (inferior a 6 meses) adquirem uma certa expressão no seio da população em causa $(4,1 \%)$. A detenção como causa da $1 .^{\text {a }}$ ruptura conhecida no grupo parental é mais elevada quando veio a suceder em relação ao pai $(3,8 \%)$ do que à mãe $(1,2 \%)$. Finalmente, para $13,8 \%$, esta ruptura deveu-se a divórcio/separação.

Atendendo à legislação e natureza dos procedimentos judiciais em vigor, no que concerne à averiguação das situações de paternidade, o número de casos que permanecia sem registo de paternidade $(2,3 \%)$ configura a existência de teias de relações sociais demasiado frágeis ou volúveis à volta da mãe. Relativamente à natureza da relação do grupo parental, quando do nascimento do jovem, existia uma prevalência de relações oficializadas sob a forma de casamento $(56,6 \%)$, seguindo-se as uniões de facto $(30,7 \%)$, enquanto $10,0 \%$ tinham nascido de relações ocasionais.

Mais de metade dos jovens viveu esta quebra de relacionamento entre os pais até aos cinco anos de idade e $1 / 3$ entre os seis e os nove anos. Estes valores diminuem à medida que a idade aumenta, o que parece ir ao encontro de algumas correntes teóricas sobre o desvio e a delinquência 
juvenis. Salientam-se, neste ponto particular, os autores situados numa linha de orientação psicossociológica que tendem a revelar como decisivas para o desenvolvimento de comportamentos desta natureza a existência de fortes perdas e distorções, em termos da construção das imagens parentais na primeira infância, decorrentes de experiências traumáticas, geralmente intensas e profundas, ao nível da própria qualidade do relacionamento e natureza da comunicação e interacção entre a criança e os que, à partida, se supunha lhe estariam mais próximos, os seus progenitores (Winnicot, 1977; Walgrave, 1992).

No aprofundamento desta linha, é importante sistematizar alguma da informação oficial, no que diz respeito à qualidade da relação entre o jovem e o pai e a mãe, considerando-a a partir de três modalidades que procuram sintetizar alguns dos dados obtidos.

Quadro 3: Natureza do relacionamento entre jovem e os pais

\begin{tabular}{l|c|c}
\hline & Relação com o pai & Relação com a mãe \\
\hline Positiva & $14,3 \%$ & $28,2 \%$ \\
Conflituosa/Rejeição/Indiferença & $29,7 \%$ & $42,8 \%$ \\
Sem contacto & $56,0 \%$ & $30,9 \%$ \\
\hline
\end{tabular}

Fonte: Inquérito ao desvio e delinquência na população dos colégios do IRS, 2000.

À volta de $56,0 \%$ não tinha contacto com o pai, enquanto o mesmo tipo de situação, em relação à figura da mãe, está assinalado em 30,9\%. Daqui ressalta, mais uma vez, a ideia não só da ausência do pai no processo educativo, mas também a existência de uma relação predominantemente conflitual quando está presente. Sabendo-se bem como nesse período a vida interior é dependente da realidade externa, a qualidade do meio envolvente de cada um tenderá a facilitar ou a impedir uma construção equilibrada da personalidade (Ferreira, 2002), estando este subuniverso marcado por trajectórias onde se viveu aos cuidados de muitos e de ninguém, em especial (Strecht, 2001).

Indo um pouco mais longe no cruzamento entre o tipo de relação entre pai e filho, verifica-se que a rejeição tende a partir mais do pai do que do filho. Em resposta, este assume uma atitude conflitual ou de indiferença ou também de recíproca rejeição. São ainda relativamente expressivos os casos em que a indiferença (apenas aparente ou não) é o principal sinal manifestado por uns e outros.

Já no que concerne ao relacionamento entre a mãe e o jovem e o jovem e a mãe, a situação é, a um primeiro olhar, um pouco mais satisfatória, 
sendo que, para pouco mais de um quarto do total, é apontada a existência de uma relação positiva. A conflitualidade, mais do que a rejeição, tende a surgir com maior incidência por parte dos jovens do que pela mãe; no entanto, a esta linha de orientação não será indiferente o facto de ela estar representada com maior incidência nos casos de rejeição para com o filho.Também nas relações em que a indiferença é a marca dominante, tende a ser a mãe a manifestar mais este tipo de atitude, sendo relativamente baixos os valores reportados às situações em que o filho, mesmo quando rejeitado ou em conflito, se revela (aparentemente(?)) indiferente face à mãe.

Da leitura destes dados transparece a ideia de como a presença física em si mesma está longe de ser suficiente, nem sempre correspondendo à adequada presença emocional, decisiva para um equilibrado desenvolvimento psicossocial. Em suma, o traçar deste quadro de fundo reflecte, como defendia Teresa Ferreira (2002), a crescente necessidade de tomada de consciência de um "declínio de afectos" que, caracterizando as sociedades modernas, adquire neste estudo uma particular (e dramática) visibilidade.

Neste campo, e considerando outros familiares que são apontados nos relatórios, destacam-se, de forma positiva, os relacionamentos com as avós e, numa segunda linha, com os avôs e os irmãos e, de forma negativa, as figuras substitutivas de um dos progenitores - padrasto/companheiro da mãe ou madrasta/companheira do pai -, muito especialmente a figura substitutiva do pai junto das raparigas.

Passando à abordagem da informação recolhida sobre a violência doméstica e vitimação, perto de $2 / 3$ destes jovens está claramente identificado como vítima regular de maus tratos na família e 3/4 foi vítima de negligências diversas por parte de diversos familiares. A associação entre maus tratos/abusos físicos e psicológicos é de longe a mais referenciada (47,5\%), seguindo-se a sobreposição entre maus tratos/abusos físicos, psicológicos e sexuais. As descrições dos factos assinalam quase sempre a existência de padrões de comportamento de extrema violência, seja qual for o tipo de mau trato mencionado. Há ainda o registo, em vários grupos domésticos, de frequentes internamentos hospitalares daí decorrentes e, em cinco, de homicídio conjugal que culminou na morte da mulher.

$\mathrm{Na}$ identificação dos agentes e vítimas mais directamente envolvidos nesta problemática, os valores mais expressivos destacam o pai como agressor, quer para a mulher e filhos (19,5\% da população), exclusivamente para os filhos $(6,4 \%)$, ou somente contra a mãe $(6,2 \%)$. Com números mais reduzidos surgem os casos em que é a mãe que atinge os filhos $(5,0 \%)$. Para além dos pais, outros familiares estão também referenciados, sobretudo figuras masculinas (tios, avô, primos, cunhados), existindo uma especial incidência para o padrasto, nos casos das raparigas. De igual modo, existe um número de referências a indivíduos ligados ocasionalmente ao pai ou mãe, a maior parte associado à prostituição. 
Numa mesma linha, realca-se os 3,8\% de jovens que passaram à condição de agressores no quadro familiar. Uma particularidade é-lhes comum: em todos os grupos domésticos de origem estão assinalados, ao mesmo tempo, outros agressores e outras vítimas. A violência exercida pelos mais novos, e em que a mãe é o principal alvo, não é manifestada de forma isolada ou meramente pontual, surgindo como a face mais visível de uma complexa teia de relações, na qual dificilmente se percepcionam os papéis desempenhados por cada um.

Por género, as raparigas $(58,3 \%)$ estão mais representadas como vítimas do que os rapazes $(38,3 \%)$, evidenciando-se mais esta orientação no campo dos abusos sexuais. Aí, metade delas está referenciada, enquanto que os rapazes se ficam pelos $12,4 \%$, embora se tenha a consciência que estes números poderão não revelar toda esta realidade.

É neste contexto que se salienta uma conflitualidade que se gera no seio das relações familiares, estendendo-se às próprias relações intergeracionais. Nestes quadros sociais revela-se significativa a ausência de modelos familiares estáveis de referência, em relação aos quais as constantes rupturas e alterações sinalizadas vêm a marcar a natureza e dimensão da interacção afectiva. Emerge um conjunto de dados que aponta para fortes perturbações nos processos de vinculação da criança à(s) pessoa(s) que dela cuidara $(\mathrm{m})$ nos primeiros anos de vida, elementos estes considerados pelos mais diversos autores como decisivos para a construção e desenvolvimento equilibrados da personalidade da criança e jovem (Muchielli, 1979; Chaillou, 1995).

Os presentes resultados sugerem a incapacidade, consciente ou não, por parte dos adultos, supostamente mais responsáveis pelas crianças, de exercerem de modo minimamente consistente e coerente a supervisão educativa que, por direito e dever, lhes é cometida.

Levanta-se, na análise deste ponto, um conjunto de profundas interrogações, que não encontram resposta nesta pesquisa, mas que se prendem com a natureza da efectiva aplicação dos direitos da criança, consagrados nacional e internacionalmente, quando os pais, por motivos de diversa ordem, se revelam incapazes ou se demitem voluntariamente do seu papel. Como efectivar a aplicação real de direitos dos mais novos se não se encontravam previstos, à data da realização deste trabalho, mecanismos de educação, apoio e maior responsabilização parental (Vidal, 1998)?

No fundo, não se poderá restringir esta questão apenas ao patamar de uma necessária responsabilização parental, que se acredita ser de grande complexidade e de contornos difíceis de precisar, até mesmo de concretizar, em termos práticos. Pela dimensão e natureza da informação recolhida, defende-se que se estará perante uma situação mais alargada de desresponsabilização social por parte da comunidade que muito facilmente 
parece tender a deixar cair para além das suas margens aqueles que maiores dificuldades de integração nela enfrentam.

Sabendo-se como a falta de modelos de identificação familiar capazes de potenciar um desenvolvimento psicossocial equilibrado "encaminha os jovens para uma 'autonomia' precoce que disfarça a rejeição precoce" (Matos, 199: 25), a fraca e distorcida qualidade dos laços familiares entre pais e filhos, traduzida na inexistência de relações próximas e intensas, parece tender a criar condições que colocam o jovem numa situação de maior vulnerabilidade perante as influências desviantes do meio. Potencialmente, a família terá mesmo deixado de se assumir como fonte de motivações para este se conformar às normas e regras sociais (Moura Ferreira, 1997).

Destacar-se-á, assim, a sobreposição de condições negativas que acentuam a necessidade de uma intervenção precoce centrada em diferentes áreas de apoio social cuja capacidade de resposta, perante os dados disponíveis, parece não ter existido ou ter sido escassa, acabando por se reforçar muito negativamente o quadro social, já por si demasiado negro, onde estes jovens se (des)integravam.

Da leitura da informação recolhida parece configurar-se uma certa dicotomia entre os papéis desempenhados por mãe e por pai, emergindo, sobretudo, uma imagem de desresponsabilização parental mais fortemente ligada à figura masculina. A caracterização do grupo parental aponta para a existência de uma diferenciação de estatuto e papéis associados aos diferentes sexos, sendo muito pertinente a constante ausência de informação relativamente ao pai decorrente da sua ausência do agregado familiar ou, mesmo quando presente, por desconhecimento sobre o seu modo de vida. A mãe tende a situar-se em idades mais novas, a possuir um nível de instrução mais baixo e a estar mais representada nos não activos e nas situações de activos em condições mais precárias do que o pai. As profissões referenciadas mais expressivamente a um e a outro remetem para uma não especialização com uma forte vertente de trabalho manual em situações de grande precariedade económica e social. É elevado o número de pais $(8,1 \%)$ e de mães $(5,1 \%)$ que se encontravam detidos, em cumprimento de pena de prisão preventiva ou efectiva.

A esmagadora maioria destes jovens não só tem irmãos $(93,0 \%)$ como ainda residia com algum (78,5\%). Analisando a natureza das relações no seio da fratria considerando exclusivamente os irmãos conhecidos, destaca-se o facto de ser, fundamentalmente, constituída por filhos do mesmo casal $(63,0 \%)$. Seguem-se as que englobam filhos de outras uniões da mãe $(19,6 \%)$, por parte do pai $(8,1 \%)$ e as que acabam por reunir outros filhos de outras relações do pai e da mãe $(7,5 \%)$, desconhecendo-se a natureza das restantes $(1,8 \%)$. No que concerne à sua colocação na fratria, para além do reduzido número de filhos únicos $(4,8 \%)$, o seguinte valor mais 
baixo refere-se aos mais velhos; com uma elevada expressão estão os que se situam em posição intercalar ou de mais novo.

Poder-se-iam aqui realçar as possíveis maiores dificuldades no exercício de uma mais eficaz supervisão parental, à medida que a idade dos filhos é menor e mais elevada a dos pais. No entanto, este argumento parece cair por terra quando se vem a perceber que tal é extensivo aos restantes elementos da fratria, independentemente da sua idade, dada a existência de um elevado número de jovens que tem, ou teve muito recentemente, um ou mais irmãos em situação idêntica de colocação institucional em colégio do Instituto de Reinserção Social (27,9\%), passando-se o mesmo em relação a $25,4 \%$ quando se considera este tipo de colocação no sistema da Segurança Social. Há um significativo número de casos em que estas duas situações são cumulativas, ligeiramente mais representadas nos indivíduos do sexo feminino do que nos do masculino.

Acaba por ficar bem claro que a questão do exercício da supervisão parental vai para além do jovem mais directamente envolvido neste estudo, estendendo-se a prática de entrada em instituição a grande parte das fratrias consideradas, existindo um elevado número de famílias em relação às quais se centra a acção directa de ambos os sistemas. Se isso corresponde a uma necessidade efectiva ou se, ao invés, realça uma intervenção, fortemente enraizada em Portugal, de promoção quase exclusiva de institucionalização, em detrimento de uma intervenção preventiva precoce centrada na própria família, é algo que fica por responder.

\section{Problemáticas sinalizadas no grupo doméstico}

Num patamar diferenciado de análise, atendeu-se à existência de problemáticas sociais identificadas oficialmente no seio dos grupos domesticos. Realce para os 73,5\% associados a pobreza; seguem-se elevadas percentagens de casos de alcoolismo $(71,2 \%)$ e de violência doméstica $(52,8 \%)$. De entre outras apresentadas, distinguem-se, em particular, dois grupos. Um primeiro envolve as designadas condutas desviantes sem prática de crime (mendicidade e prostituição) e a toxicodependência, atingindo valores na ordem dos 47,2\% e 39,4\%, respectivamente. O segundo abrange práticas criminais recenseadas no sistema prisional por parte de membros do grupo doméstico, seja no passado $(27,2 \%)$, seja à data da entrada em colégio do jovem $(18,6 \%)$. Neste último, destacam-se, sobretudo, os pais detidos, a maioria associada ao tráfico ou consumo de droga.

Apenas em $6,4 \%$ da população não se encontra assinalada qualquer uma destas problemáticas, havendo, pelo menos, a referência a uma nos restantes $93,6 \%$ que destacam possíveis agregações entre um conjunto de factores de risco social. Tal coloca os actores sociais directamente atingi- 
dos em situações de maior vulnerabilidade e, até mesmo, marginalidade, que tenderá a ser reforçada na ausência de uma intervenção social que não tenha como ponto de partida uma visão integrada e coerente do todo.

\section{Conclusão}

A informação sobre a incidência e natureza das condutas desviantes e delinquentes não pode ser considerada isoladamente no mero conhecimento dos actos cometidos, tendo de ser analisada sob os pontos de vista sociocultural e económico do meio onde se produzem. Recordando que este artigo se limita à apresentação de uma parte dos resultados da análise univariada relativa ao contexto familiar de uma investigação mais vasta, importa reter que a informação obtida remete para processos de objectivação da actividade humana desenvolvidos por agentes de mecanismos de controlo formal, à luz de quadros jurídicos específicos reportados a um tempo e espaço determinados, não sendo possível a sua directa transposição para outro contexto que não exclusivamente o aqui considerado.

Este trabalho centrado no discurso construído por determinados actores sociais patente nos documentos oficiais consultados em dossier tutelar, não tem em linha de conta o que os próprios sujeitos envolvidos teriam para dar a conhecer acerca dessa leitura e de si, numa perspectiva que assentaria na construção provável de um outro discurso (Luckam e Berger, 1973), imprescindível para um melhor conhecimento sobre esta realidade.

Dos condicionamentos decorrentes do acesso ao próprio objecto de estudo e da natureza e dimensão desta pesquisa ${ }^{17}$, o conjunto de opções metodológicas reflecte um determinado olhar traçado à luz de objectivos específicos que potenciam uma certa perspectiva em detrimento de outras. $\mathrm{Na}$ base desta linha de orientação, salienta-se a pertinência de trazer para discussão os principais contornos de uma visão construída sobre a realidade social, visão esta que fora determinante na aplicação da Lei por parte

17 No início da pesquisa estava prevista uma abordagem complementar, a concretizar junto dos jovens e das famílias, orientação que, por imperativos de ordem legal (impedimento de acesso às famílias através do dossier tutelar nos termos do parecer emitido pela Comissão de Acesso a Documentos Administrativos, sediada na Assembleia da República) e a antecipação da entrada em vigor da Lei Tutelar Educativa de 1 de Setembro para 1 de Janeiro de 2001, por Resolução do Conselho de Ministros de Agosto de 2000, na sequência de acontecimentos amplamente mediatizados sobre condutas delinquentes de jovens nesse Verão, levaram a que se tivesse limitado o estudo à identificação dos percursos de vida dos jovens afectos, a nível nacional, aos 14 colégios do Instituto de Reinserção Social. A não existência de um quadro de fundo sobre este sistema que reunisse um mínimo de indicadores estatísticos inviabilizou a constituição de uma amostra representativa e reforçou a necessidade de traçar o retrato sociográfico aprofundado sobre esta população, na fase final de aplicação do modelo legal então vigente. 
dos Tribunais, centrada numa aparente factualidade que não era objecto de maior discussão, ou até, sequer, de necessidade de qualquer prova.

Como sugere Cusson (1989), a propósito do funcionamento das instâncias judiciais um pouco por todo o mundo, quanto mais uma criança ou jovem provir de um meio familiar e social desfavorecido, mais elevadas serão as suas probabilidades de ser colocado perante as instâncias judiciais, radicando o cerne desta questão, ainda segundo esse autor, na natureza e eficácia dos mecanismos de controlo informal, designadamente, a família. A esta acresce o olhar selectivo e segregador que, à partida, tende a condicionar a acção dos mecanismos de controlo formal (Le Blanc, 1977). Na colocação em jogo de certos "factos" originados a partir de uma situação de denúncia, esta realidade, construída como parte de uma realidade mais vasta, revela um outro sentido do real, na plena medida em que o tribunal age sobre ela determinando a sua evolução. Servindo de índice mais ou menos duradouro de processos que partem de um grau de intersubjectividade dos seus produtores, permitindo que se estendam para além da situação face a face em que deverão ter sido directamente apreendidos, como se de retratos ordenados se tratassem, os documentos oficiais evidenciam a tentativa de estruturação espacial e temporal da vida dos jovens que foi tornada acessível para este efeito (Luckmann e Berger, 1973).

Nesta ordem de ideias, teve-se oportunidade de verificar, ao longo da investigação, como os percursos de vida individuais só farão sentido mais completo quando lidos numa perspectiva que integre as condições estruturais que constrangem e condicionam a acção individual, constituindo o pano de fundo sobre o qual cada indivíduo continuamente exprime, sofre, interpreta e refaz a sua interacção com os outros.

Dificilmente se poderá ignorar, à luz da expressão de muitos dos resultados obtidos, a forma como um conjunto de variáveis, individuais e sociais, parece destacar-se na associação a comportamentos e actos desta natureza, evidenciando-se uma interacção social de contornos negativos e onde a qualidade das relações na família emerge como um dos aspectos centrais, acentuando uma vulnerabilidade social já de si atravessada por deficientes condições socioeconómicas e habitacionais.

Ao privilegiar-se a identificação da plasticidade e variabilidade dos sistemas familiares, os espaços de socialização familiar destes jovens revelam-se oficialmente sinalizados pela existência de relações de natureza conflitual e pela necessidade da sua adaptação permanente a grupo doméstico caracterizado pela privação afectiva, quebras de laços familiares e ausência (física e/ou emocional) das figuras parentais, sobretudo por parte do pai.

Dos riscos intrínsecos a estes processos identificados por diversos autores - famílias numerosas, supervisão parental insuficiente ou inadequada; ausência de um ou dos dois progenitores do processo educativo, envolvimento da família em práticas criminais, distorção nas relações intrafami- 
liares (Farrington, 2001; Kumpfer e Alvarado, 2003) -, não se detectou em contraposição uma efectiva acção de outros mecanismos de controlo informal, designadamente, em termos de possíveis redes de vizinhança que pudessem ter vindo a constituir-se como referência adequada para estes jovens. Os quadros identificados apontam, em muitos dos casos, para percursos de infância, por vezes reportados até ao período anterior da gravidez ou à sua fase imediata, caracterizados por sucessivas rupturas e quebras não apenas nos laços familiares, mas também a outros de natureza social.

Tende a emergir uma diversidade de factores adversos no seio do núcleo familiar, que rápida e frequentemente se desfaz, mas dificilmente se (re)compõe, numa multiplicidade de formas em que a instabilidade, a violência recorrente e a ausência de figuras permanentes de referência transparecem como imagem de marca, apontando para que este núcleo tenha deixado de funcionar como efectivo e, mais que necessário, equilibrado suporte afectivo.

Em função de influências sociais que jovens e famílias sofrem através de interacções recíprocas em planos similares, e a cujas contingências reagem das formas possíveis, a violência poderá ter sido a mais forte ou, até mesmo, a única forma de comunicação aí existente. O peso destrutivo do abandono (físico e/ou emocional), dos maus tratos, da negligência, da solidão, aqui traduzida de maneira intensa em modos de vida assentes numa falsa (e desesperada) autonomia em percursos em que muito cedo estes jovens se viram entregues a si próprios, contrasta com a necessidade de satisfação de necessidades psicossociais básicas fundamentais à sua futura evolução e à construção da sua identidade social. São situações que se revelam nos seus contornos mais graves, na existência de cerca de $17 \%$ da população que, à entrada em colégio, já não residia com qualquer familiar; com realce para os $8,2 \%$ identificados em vivências nas margens da sociedade, sozinhos ou em grupos de pares, em condições muito pouco claras. A profundidade com que esta questão se revela aponta, neste estudo, para que o deficiente, ou até mesmo inexistente, grau de monitorização ou supervisão parental se destaque como factor de risco preponderante em todo este processo. Tal deriva de alterações no grupo parental em que mais do que o divórcio/separação é o abandono de um dos progenitores (ou de ambos) que constitui o principal motivo deste tipo de ruptura. Segue-se um elevado número de casos em que, especialmente, o pai faleceu em idade relativamente nova. Trata-se de um contínuo de intensas perdas relativamente a quem se esperaria pudesse estar mais próximo: os próprios pais.

Mais do que encontrar respostas, este trabalho obriga ao levantamento de questões sobre as dinâmicas e mudanças sociais em Portugal, na certeza, porém, de que o universo aqui retratado, reportado a um modelo de intervenção jurisdicional que deu lugar a outro diferenciado, constituirá apenas a face mais visível, porque mais desfavorecida e já recenseada ofi- 
cialmente, da problemática da delinquência juvenil em Portugal, no período estudado.

Da necessidade de efectivação de uma intervenção precoce integrada, focalizada na família que estes dados deixam transparecer, tem sido privilegiadas acções de remediação, como a que é levada a cabo no sistema de justiça tutelar de menores, em idades muito mais tardias e quando os problemas assumem uma outra visibilidade e contornos de maior gravidade. A identificação da família como núcleo central das políticas de acção social terá de atender a necessidades de diversa ordem, para a qual a responsabilização parental só poderá fazer sentido se associada às áreas da educação e apoio parental, formação em competências parentais e familiares, terapia e mediação familiar, em programas de longa duração (Kumpfer e Alvarado, 2003), sem os quais dificilmente as situações aqui retratadas de abandono e negligências deixarão de existir.

Da identificação de factores de risco referenciados em vários estudos (Farrington, 2001), alguns dos quais também aqui sinalizados, torna-se necessário passar para um modelo de prevenção comunitária que combine medidas de acção social com outras de âmbito situacional, fortalecendo a família como unidade em si mesma. Mais do que a mera actuação oficial com vista à diminuição dos factores de risco, deverá ser proporcionado o desenvolvimento dos mecanismos familiares de resiliência e protecção, designadamente, ao nível das relações entre pais e filhos, da monitorização e supervisão parental e do reforço da educação da própria família.

Porque os números apresentados não são números em abstracto, reportam-se a momentos e acontecimentos específicos na vida destes jovens, aguarda-se apenas que não se fique à espera da prática de um acto ilícito, agora fundamental e decisiva para a colocação em centro educativo, para que determinados mecanismos sociais venham a ser accionados junto da família e não exclusivamente junto do jovem, ignorando-se todos os sinais anteriores, como terá acontecido em grande parte da população que foi objecto deste estudo.

\section{Referências}

Agra, C., \& Matos, A. (1997). Trajectórias desviantes (Colecção Droga-Crime: Estudos Interdisciplinares, vol. 11). Lisboa: Gabinete de Planeamento e Coordenação do Combate à Droga, Ministério da Justiça.

Almeida, A., André, I., \& Almeida, H. (1998). Relações familiares: Mudança e diversidade. In A. Costa \& J. Viegas (Eds.), Portugal, que modernidade? (pp. 45-76). Oeiras: Celta Editora.

Almeida, A. (2000). A sociologia e a descoberta da infância: Contextos e saberes, Forum Sociológico, 3-4. 
Becker, H. (1963). Outsiders. New York: Free Press.

Berger, P. L., \& Luckmann, T. (1973). A Construção Social da Realidade. São Paulo. Editora Vozes.

Binder, A., Geis, G., \& Dickson, D. (2001). Juvenile delinquency. Ohio: Anderson Publishing Co.

Boudon, R. (1979). La logique du social. Paris: Hachette.

Bourdieu, P. (1979). La distinction. Une critique sociale du jugement. Paris: Les Éditions de Minuit.

Burguiére, A. (1996). "Pour une typologie des formes d'organisation domestique de l'Europe moderne (XVIe-XIX siècles)", Annales, 3, ??- ??.

Cario, R. (1999). Jeunes délinquants. À la recherche de la socialization perdue. Paris: L'Harmattan.

Carvalho, M. J. (2003). Entre as malhas do desvio. Jovens, espaços, trajectórias e delinquências. Oeiras: Celta Editora.

Catalano, R., \& Hawkins, D. (1996). Delinquency and Crime. Current Theories. Nova Iorque. Cambridge University Press.

Castro, J. (1997). Socialização das Crianças de Rua e Lógicas de Intervenção das Redes de Suporte Social. Cadernos do CEJ, 19.

Chaillou, Philippe (1995). Violence des jeunes, l'autorité parental en question. Paris: Gallimard.

Cohen, A. (1971). La déviance. Gemblaux: Éditions J. Duculot, SA.

Cusson, M. (1989). Délinquants pourquoi?. Quebeque: Bibliothèque Nationale du Québec.

Cusson, M. (1998). Criminologie actuelle. Paris: Presses Universitaires de France.

Dias e Andrade (1984). Criminologia, o homem delinquente e a sociedade criminógena. Coimbra Editora.

Epifânio, R., \& Farinha, A. (1997). Organização tutelar de menores: Contributo para uma visão interdisciplinar do direito de menores e da família (vol I, 2 ed.). Coimbra: Almedina (reimpressão de Organização Tutelar de Menores, 1978).

Farrington, D. (2001). Prevenção centrada no risco, Infância e Juventude, 3, 9-31.

Ferreira, T. (2002). Em defesa da criança. Teoria e prática psicanalítica da infância. Lisboa: Assírio e Alvim.

Gersão, E. (1994). Menores agentes de infracções: Interrogações acerca de velhas e novas respostas. Revista Portuguesa de Ciência Criminal, 4 (2), 241-259.

Hirschi, T. (1969). Causes of delinquency. Nova Jersey: Transaction Publishers.

Kellerhals, J., Troutor, J. Y., \& Lazega, E. (1989). Microssociologia da família. Mem Martins: Edições Europa América.

Kumpfer, K., \& Alvarado, R. (2003). Intervenções eficazes de reforço da família. Infância e Juventude, 2, 89-136.

Laslett, P., \& Wall, R. (Eds) (1978). Household and family in past time. Londres: Cambridge University Press.

LeBlanc, M. (1977). La délinquance à l'adolescence. La délinquance cachée à la délinquance apparente. Annales de Vaucresson, 14, 15-50.

Lourenço, N., \& Carvalho, M. J. (2001), Violência doméstica: Conceito e âmbito. Tipos e espaços. Themis, II (3), 95-121.

Machado Pais, J. (1996). Culturas juvenis. Lisboa: Imprensa Nacional.

Matos, M. (1996). Adolescer e delinquir. Análise Psicológica, 1 (XIV), 23-29. 
Merton, R. (1970). Sociologia, teoria e estrutura. São Paulo: Editora Mestre Jou.

Ministério da Justiça (1978). Organização tutelar de menores, Decreto-Lei $\mathrm{n}^{\circ} 314 / 78$, de 27 de Outubro.

Ministério da Justiça (1999). Lei tutelar educativa, Decreto-Lei nº166/99, de 14 de Setembro

Ministério do Trabalho e Solidariedade Social (1999). Lei de protecção de crianças e jovens em perigo, Decreto-Lei ${ }^{\circ} 147 / 99$, de 1 de Setembro.

Moura Ferreira, P., Garcia, L., \& Vala, J. (1993). Delinquência e criminalidade recenseada dos jovens em Portugal (1980-1989). Cadernos do Instituto de Ciências Sociais, 4.

Moura Ferreira, P. (1997). 'Delinquência juvenil', família e escola. Análise Social, XXXII (143), 913-924.

Muchielli, R. (1979). Comment ils deviennent delinquants. Paris: Les Éditions ESF.

Queloz, N. (1994). Fenómenos e dissociação do laço social, comportamentos desviantes dos jovens e intervenções sociais. Infância e Juventude, 4, 9-32.

Roché, S. (1998). Société complexe, modernité et insecurité. Révue Internationale de Criminologie et de Police Technique et Scientifique, LI (4), 387-394.

Rodrigues, L. , Antunes, C., \& Mendes, Z. (1997). Padrões de consumos e desvância em menores sob tutela (Colecção Droga-Crime: Estudos Interdisciplinares). Lisboa: Gabinete de Planeamento e Coordenação do Combate à Droga, Ministério da Justiça.

Roussel, L. (1992). O futuro da família. Sociologia, Problemas e Práticas, 11, $165-$ -179 .

Saraceno, C. (1992). Sociologia da família. Lisboa: Editorial Estampa.

Sebastião, J. (1995). Modos de vida marginais: O caso das crianças da rua de Lisboa. Infância e Juventude, 2, 47-69.

Selosse, J. (1995). Adolescence, violences et déviances (1952-1995). Paris: Éditions Matrice.

Selosse, J. (1976). As causas da delinquência juvenil. Infância e Juventude, 3, 24-28 .

Sousa Santos, B. et al. (1998). A justiça de menores. As crianças entre o risco e crime (Relatório do Observatório Permanente da Justiça Portuguesa, vol. 4). Coimbra: Centro de Estudos Sociais da Faculdade de Economia da Universidade de Coimbra.

Strecht, P. (2001). Interiores: Uma ajuda aos pais sobre a vida emocional dos filhos. Lisboa: Assírio e Alvim.

Vala, J. (1985). Contribuições para uma análise psicossocial da delinquência. Infância e Juventude, 2, 53-65.

Vidal, J (Ed..) (1998). O Direito de menores: Reforma ou revolução. Cadernos da Revista do Ministério Público, 9.

Walgrave, L. (1992). Délinquance systematisee des jeunes et vulnerabilite societale (Collection Déviance et Société). Genebra: Éditions Médecine et Hygiène.

Winnicot, D. (1977). Deprivation and delinquency. Londres: Karnac Books. 